\title{
Bankruptcy Prediction for Non-Financial Firms of Pakistan
}

\author{
Muhammad Sohaib Roomi \\ Department of Business Administration, Faculty of Management Science \\ National Textile University, Faisalabad Punjab, Pakistan \\ ranaroomi66@gmail.com
}

Waqas Ahmad

Department of Business Administration, Faculty of Management Science

National Textile University, Faisalabad Punjab, Pakistan

waqasntu5059@gmail.com

Muhammad Ramzan

Department of Business Administration, Faculty of Management Science

National Textile University, Faisalabad Punjab, Pakistan

ramzan_ntu@live.com

Muhammad Zia-ur-Rehman

Department of Business Administration, Faculty of Management Science

National Textile University, Faisalabad Punjab, Pakistan

zia.msfin@iiu.edu.pk

DOI: 10.5296/ijafr.v5i2.7782 URL: http://dx.doi.org/10.5296/ ijafr.v5i2.7782

\begin{abstract}
In this study we use two models for the measuring of financial status of the non-financial firms which are listed in the Karachi Stock Exchange. The Non-financial companies represent the biggest slice at the Karachi Stock Exchange. The non-financial companies of Pakistan are the total population and sample size is 25 higher and 25 lower capital companies. The




\section{MInstitute Macrothink $_{\text {Int }}$}

International Journal of Accounting and Financial Reporting ISSN 2162-3082 2015, Vol. 5, No. 2

technique which used in this study was Convenience sampling technique and all 50 non-financial listed companies at KSE were included to gain deeper insights into this study. The State Bank of Pakistan shows balance sheet analyses of companies, for compiling of data financial reports were used for the years 2007 to 2012. The results of the study showed that Abbas model and Altman's Z-Score model was a effective tool for checking the financial health of non-financial companies listed at Karachi stock exchange. This study further explores that lower capital firm have more financially distressed companies as compare to high capital non-financial companies listed at KSE.

Keywords: KSE 100, Z-Score, bankruptcy, financial ratios, discriminant analysis

\section{Introduction}

In the context of the present financial disaster, macro-economic actions are evaluating in the research field of such prediction of concerning. Instead, the main point of our research was set at the level of micro-economic factors. Due to many reasons like ineffectiveness in management also cause the default of corporation. (in managing the risk, debt and cash), specific reasons of industry such as overloading or deregulation, for define period with the interest of high rates, and strict competition of global (Altman, 2006). In slump period increase in the number of failure due to the decrease of GDP in trend number (Hol, 2007). There are many researches which have been conducted at the bankruptcy of corporate and its implication for asset pricing in order to develop new investment strategies. For accurate and developing valid models for the prediction of failures prior to the unpleasant incident can help the stakeholders to take protective actions to reduce the possible losses; thus, constructing such prediction models and testing their predictive ability is essential.

The results have been confusing with some studies (e.g. Dichev (1998); Griffin and Lemmon (2002); Campbell et al. (2008), and Agarwal and Taffler (2008) finding a negative association between distress risk and equity returns, while others (e.g. Vassalou and Xing (2004), and Chava and Purnanandam (2010)) reported a positive relation. The process of bankruptcy prediction methods and their models which starts with the decisive research of Beaver (1966) and Altman (1968) has a vast literature. Mostly the studies of them focus on constructing the models, comparison of different models with their predictive capacities and the performance of different models. Professor Edward Altman developed the Z-Score, for predicting the financial distress the Z-Score is perhaps the applied and most widely recognized model (Bemmann 2005). The Altman derived this spontaneously appealing scoring technique at a time when traditional ratio analysis was losing favour with school (Altman 1968). By using the model of the(MDA), the Professor Altman narrowed a list of twenty two(22) potentially significant ratios to five (5) that, as a set, proved significant in predicting bankruptcy in his sample of sixty six (66) corporations (thirty three (33) bankruptcies and thirty three (33) non-bankruptcies).

Ohlson thought that nine (9) independent variables helped him in the predicting of bankruptcy, but not mentions the academic explanation for selection. Ohlson then selected the industrial firms which are traded in the stock exchange of United States for at least 3 years. 


\section{MInstitute Macrothink $_{\text {Int }}$}

International Journal of Accounting and Financial Reporting

He come to conclusion that one hundred and five (105) firms failed and two thousands (2000) firms remain un-failed. Estimation happens due to three models: the first one is for the prediction of failure within 1 year, the second model is to predict the failure in 2 years and the third one is to predict the failure in the years 1 or 2 . By using each model he is in position to predict probability of failure of companies through logistic function.

\subsection{Significance of Study}

There has been no exploration of the insolvency in Pakistan, and especially in Pakistan none of the international research has focused. So, in the area of Pakistan for the filling of the gap for the prediction of bankruptcy in this study is considered as a primary step. So in Pakistan with the help of this study in the corporate sector the findings would provide help for timely enhancing and ministration the companies of their financial position. By using exact forecasting models based on the availability of the data, managers would be in a position to make corrective actions to predict the early warning indicators. There are many other advantages that could come into action.

\subsection{Objectives}

Following are the main objectives of study:

1. To predict the bankruptcies among major non-financial companies of KSE.

2. Comparison of the performance between different bankruptcies models.

\section{Review of Literature}

Altman emphasize the worth of accounting information and claims that financial ratios should not be viewed as too simplistic .Taffler says that information in financial statements to be separate and central and highlights its value when considered in multi-ratios models. Notably accounting information such as liquidity and leverage eventually builds the decision basis for a bankruptcy filing. Decisions about the bankruptcy event are built on accounting information and not on market data.

Further, at the end of the forecasting horizon (one year) the BSM framework assumes bond maturing of a single zero coupon. However, most firms have more complex capital structure with several coupon bearing loans with different maturities. Agarwal and Taffler (2008) also argue that the BSM framework assumes costless bankruptcy, no safety covenants, and, unless the down-and-out barrier option framework is applied, default is triggered only at maturity without taking into account that the company can default earlier. The literature suggested that the prediction models of generic bankruptcy when applied loose accuracy if applied to one industry. This was tested by the model of the Schumway (2001). They used a sample of the forty (40) over retail firms.

Also estimate the probability of insolvency by tested hazard model by Schumway in 2001 . He contested the prediction capacity of what he called, "Static Models (data from a single period). He argues that by testing the 'hazard model', half of the variables employed by Altman Z-score (1968) are not related to the insolvent probability at all. Data set that was actually subjected to the analysis included only non-financial publicly-traded firms. Specific requirements were met and targets were reached. The majority consensus seemed to be that 
publicly-traded firms were more homogeneous. Values in the extreme bracket were therefore eliminated.

One must take into account and indeed ponder over the interesting point that, while predictions of bank failure, non-financial corporate default and financial distress have been extensively debated in various studies and journals, the vulnerability of companies to short-term funding shocks (which are likely to cumulate and can lead to organization failure) has received little attention in the Pakistani economic realm.

The main focus of this study is to fill the void and cracks over looked in economic literature. The techniques proposed by the various researches above have unquestionable the advantages and at the same time questionable limitations. Lacking in the standardized insolvency theory has lead research to explore the D/W types of the techniques and approaches according to their unique structure of the corporate environment and the country (Etemadi et al., 2008).

Guscinskiene and Ciburiene (2010) studied the respondents' view on the situation of men and women in the labour market. Empirical study showed that $42 \%$ of women and $26 \%$ of men have never lost their jobs and the people who have, have mentioned several reasons for this. Respondents, both women and men, generally lose work because of inadequate working conditions and the company's bankruptcy. After the bankruptcy dynamics in Lithuania and the analysis of bankruptcy prediction importance, the prediction of the models of the bankruptcy prediction commonly used in scientific literature was given a systematic way by Rugenytė et al. (2010).

The limited liability sector in the country of the Norway, Dakovic et al. (2010) pioneered statistical models for bankruptcy prediction of Norwegian firms using their annual balance sheet information. Their conclusions were that after the careful examination of the functional relation-ship between the explanatory variables and the probability of bankruptcy, the models' forecasting performance was enhanced. It can be concluded that there are vast of researches on bankruptcy prediction models. Only few researchers make model of bankruptcy prediction in Pakistani context with comparison of other models. According to my knowledge existing researches are not showing any prediction on the bankruptcy in Pakistani nonfinancial sectors.

\section{Hypothesis Development}

H1: The financial health of the companies is significant difference by using Abbas model and Z-score model.

H2: Financially distressed company exist among non-financial listed companies at Karachi stock exchange.

H3: More than 500 million paid up capital companies are more expected to fail.

\section{Research Methodology}

\subsection{Sample}

In each non-financial sector two companies are selected from upper side and lower side, so the sample size will be 25 upper and 25 lower companies and the total sample size will 50 companies during the period of 2007-2012. 
For selecting the sample the criteria are followed as below:

1. All types of companies their shares have been traded at the Stock Exchange of Karachi in the period of listing and register with SECP (security exchange commission of Pakistan).

2. The sector which is selected only the sector of non-financial. Because the atmosphere are diverse in the financial sector.

3. The financial information of the company must have at least five years.

\subsection{Data Analysis Models}

The study of MDA as leading/dominant technique by Altman(1968). The bankruptcy prediction has high predictive ability through the study of MDA. Abbas and Rashid (2011) model use for testing because they test model and predict bankruptcy in Pakistan. The dependent variable of these models predicts the insolvency possibility of the company in year. That variable show black zone that takes the value -1 and white zone that take the value not less than for any non-financial firm in observation.

\subsubsection{Altman (1968) Model:}

In 1968 the Altman derive a "Z Score" in which he formed a new model by the combination of five ratios with the extenction of Beaver's approach. Especially for the companies which are manufacturing, the developed model outperformed the approach of Beaver's in the prediction of insolvency, i.e:

$$
\begin{aligned}
& Z=V_{1} X_{1}+V_{2} X_{2}+V_{3} X_{3}+V_{4} X_{4}+V_{5} X_{5} \\
& Z=1.2 X+1.4 X+3.3 X+0.6 X+1.0 X
\end{aligned}
$$

Where,

$V_{1} V_{2} \ldots, V_{n}=$ Discriminant coefficients

$X_{1}=$ Working Capital over T.A(total assets)

$X_{2}=$ R.E over T.A

$X_{3}=$ E.B.I.T over T.A

$X_{4}=$ Market Value of Equity over T.L(total liabilities)

$X_{5}=\mathrm{S}$ (sale) over TA

\subsubsection{Abbas and Rashid Model:}

Abbas and Rashid (2011) use Multi Discriminate Analyses technique determines a group of a discriminate coefficient and change a single variable values to a individual discriminate score or the value of $\mathrm{Z}$-score which is then used to categorize the objective.

The developed model through MDA is shown as fellows.

$$
Z=\beta_{1} X_{1}+\beta_{2} X_{2} \ldots \ldots \beta_{n} X_{n}
$$

$\mathrm{Z}$ is the overall index, $\beta_{1}, \beta_{2}, \ldots \ldots, \beta_{n}$ are discriminate coefficients, $X_{1}, X_{2}, \ldots \ldots, X_{n}$ are independent variables. Zero is the cut off and the midpoint value through which it describes that the moving of the companies towards positive zero is called as non-bankruptcy through the value of Z-score where on the other hand the companies which are going on the negative side are called as bankruptcy same with the help of Z-score at each of the year. At last, the 


\section{Mll Macrothink}

International Journal of Accounting and Financial Reporting

ISSN 2162-3082

2015, Vol. 5, No. 2

firm having a $\mathrm{Z}$ value $=-0.724$ classified as failure and the firm having a $\mathrm{Z}$ value $=0.724$ classified as non-failure Abbas (2011).

$$
Z=1.147 X_{1}+0.701 X_{2}-.0732 X_{3}
$$

$X_{1}=$ Sales divided by total assets ratio

$X_{2}=$ Earning Before Interest rate andTaxation divided by liabilities of current ratio

$X_{3}=$ Cash flow ratio

\section{RESULTS}

Abbas Model is the basic test of evaluating the financial position of Pakistani companies. If the Abbas Model is more than zeroit shows that if the company position is strong or the company is in the position to meet its long term commitments it shows that the company is in the boom period, and if it is less than zero then it show that the position of the company is week or it is difficult to meet its short term commitments. According to Altsman Z-Score, the financial position of a company is weak or unhealthy if its cut-off value is less than or equal to 1.81 , and if the cut off value is more than 1.81 then its position is considered as strong and healthy.

Table 4.1 Criteria for the financially failure and non failure company under Abbas Model and Altsman Model.

Table 4.1: Criteria for Non- Failure and Failure Companies

\begin{tabular}{|l|c|c|}
\hline Method & Failure Company & Non-Failure Company \\
\hline Abbas Model & $<0$ & $\geq 0$ \\
\hline Altman Z-Score & $<1.81$ & $\geq 3$ \\
\hline
\end{tabular}

Altsman model and Abbas model is measured for the fifty non-financial companies. By testing the first hypothesis, using SPSS the paired sample $t$ test was conducted and by testing second hypothesis, according to criteria number of expected failed and non-failed companies show the results mentioned in table 4.1.

In Table 4.2 it represents the paid-up capital of the companies in this study. Out of total fifty companies, twenty five companies had paid-up capital less than Rs. 500 million and 25 companies have more than Rs. 500 million. Table 2: Paid-up Capital of Companies Studied

\begin{tabular}{|l|l|}
\hline Paid-up capital (in millions of rupees) & No. of Companies \\
\hline Less than 500 & 25 \\
\hline More than 500 & 25 \\
\hline Total & 50 \\
\hline
\end{tabular}

In the first figure it shows the industry averages of Abbas Model and Altman's model for the year 2007 to 2012. In 2007, Abbas Model is1.47 and Z-Score is 2.18 but in 2008 Abbas model 1.3 and Z-score are2.14. Both the results were showing continually increase from 2010 t0 2012 but only Abbas Model average decreas 1.27 and Altman Z-score Model decreas in 2008 2.14. Decreas in average of both Model show due to different economic and political 


\section{Macrothink}

International Journal of Accounting and Financial Reporting ISSN 2162-3082 2015, Vol. 5, No. 2

factors like energy problems, uncomfortable security and instability of political sector are the reasons behind this unsatisfactory position.

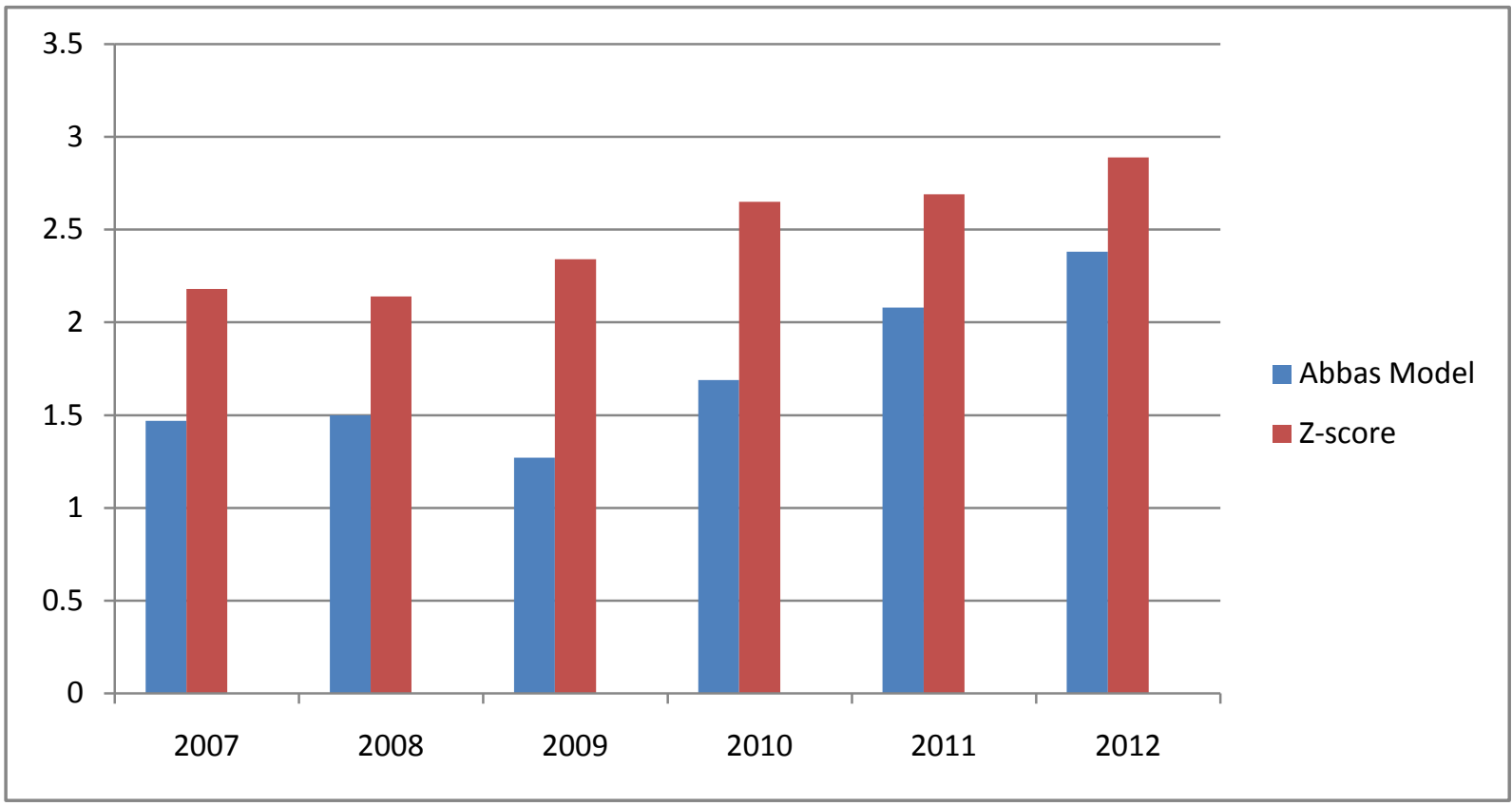

Fig. 1: Non-Financial Average for Abbas model and Z-Score

Test the first hypothesis based on table 4.3at 95\% percent significance level. By using Abbas Model and Altman Z-score at sample size of 50, it can be said that there is significant difference in using Abbas Model and Altman Z-Score Model in 2007, 2009 and 2010 due to significant value (p). There are significant difference exits in using Abbas Model and AltmanZ-Score based on Altman's 1968 Model as an indicator of financial failure and non-failure in 2008, 2011 and 2012.

Table 4.3: Comparison of Abbas Model and Altman's Model Using Paired T-Test in SPSS from 2007 to 2012 year,

\begin{tabular}{|l|lll|l|l|l|l|}
\hline Year & \multicolumn{2}{|l|}{ Variable Compared } & $\mathbf{N}$ & Mean & $\mathbf{T}$ & Significant Level (p) \\
\hline 2007 & $\begin{array}{l}\text { Abbas Model and Altman } \\
\text { Z-Score }\end{array}$ & 50 & 0.71160 & 2.60 & 0.012 \\
\hline 2008 & $\begin{array}{l}\text { Abbas Model and Altman } \\
\text { Z-Score }\end{array}$ & 50 & 0.63580 & 1.610 & 0.114 \\
\hline 2009 & $\begin{array}{l}\text { Abbas Model and Altman } \\
\text { Z-Score }\end{array}$ & 50 & 1.0674 & 3.076 & 0.003 \\
\hline 2010 & $\begin{array}{l}\text { Abbas Model and Altman } \\
\text { Z-Score }\end{array}$ & 50 & 0.9514 & 3.369 & 0.001 \\
\hline 2011 & $\begin{array}{l}\text { Abbas Model and Altman } \\
\text { Z-Score }\end{array}$ & 50 & 0.6164 & 1.726 & 0.091 \\
\hline 2012 & $\begin{array}{l}\text { Abbas Model and Altman } \\
\text { Abbas }\end{array}$ & 50 & 0.5094 & 0.575 & 0.568 \\
\hline
\end{tabular}




\section{Z-Score}

According to table 4.4 Abbas model represents the value less than 0 as expected financially failure and greater than 0 shows expected non-failure. But on the other side the Altman Z-Score Model shows that the company is expected failure when cut-off value is less than 1.81 and expected non-failure when cut-off value is more than 1.81 .

Now the analysis related to less than 500 million paid up capital companies in $2007 \mathrm{Z}$-score shows that 19 companies are declared fail and 6 are non-failed. Mean while in 2008 eighteen companies are again expected to fail but seven are non-failed out of 25 companies. The discussion about 200914 companies are declared fail and remaining companies are non-failed. The number of non-failure companies are increased in 2010 then the failure companies. In 2011 the same situation is revealed because just 8 companies are in failure situation but 17 companies are non-failure. The analysis of 2012 shows that only 9 companies are declared failure but 16 are non failure.

Abbas model shows that in 2007 there is no company expected to fail. 2008 also shows the same situation related to no failure. The analysis of 2009, 2010 and 2011 has declared only 1 Failure Company in these years. In 2012 two companies are declared failed rather than the remaining companies.

The analysis of more than 500 million paid up capital companies in $2007 \mathrm{Z}$-score shows that 13 companies are declared fail and 12 are non-failed. Mean while in 2008 fourteen companies are again expected to fail but eleven are non-failed out of 25 companies. Results about 2009 failure and non-failure companies are same like 2007. The non-failure companies are 14 in 2010 and 2011 but the failure companies are 11. The analysis of 2012 shows that only 6 companies are declared failure but 19 are non-failure.

Abbas model shows that in 2007 there are 2 companies expected to fail and 23 non-failed. 2008 also shows the same situation related to no failure. The analysis of 2008, 2009 and 2010 has declared only 1 Failure Company in these years. In 2011 and 2012 no one company are declared failed according to set criteria.

Table 4.4: Expected Financially Failure and Non-Failure Less than and more than 500 million rupees companies Status as per Abbas Model and Altman Z-Score,

\begin{tabular}{|c|c|c|c|c|c|c|}
\hline \multicolumn{7}{|c|}{ Less than 500} \\
\hline Year & $\begin{array}{l}\text { Z-Score } \\
\text { Expected } \\
\text { Failure }\end{array}$ & $\begin{array}{l}\text { Z-Score } \\
\text { Expected } \\
\text { Non-Failure }\end{array}$ & Total & $\begin{array}{l}\text { Abbas Model } \\
\text { Expected } \\
\text { Failure }\end{array}$ & $\begin{array}{l}\text { Abbas Model } \\
\text { Expected } \\
\text { Non-Failure }\end{array}$ & Total \\
\hline 2007 & 19 & 6 & 25 & 0 & 25 & 25 \\
\hline 2008 & 18 & 7 & 25 & 0 & 25 & 25 \\
\hline 2009 & 14 & 11 & 25 & 1 & 24 & 25 \\
\hline 2010 & 11 & 14 & 25 & 1 & 24 & 25 \\
\hline 2011 & 8 & 17 & 25 & 1 & 24 & 25 \\
\hline
\end{tabular}




\begin{tabular}{|l|l|l|l|l|l|l|l|}
\hline 2012 & 9 & 16 & 2 & 23 & 25 \\
\hline Year & $\begin{array}{l}\text { Z-Score } \\
\text { Expected } \\
\text { Failure }\end{array}$ & $\begin{array}{l}\text { Z-Score } \\
\text { Expected } \\
\text { Non-Failure }\end{array}$ & Total & $\begin{array}{l}\text { Abbas Model } \\
\text { Expected } \\
\text { Failure }\end{array}$ & $\begin{array}{l}\text { Abbas Model } \\
\text { Expected } \\
\text { Non-Failure }\end{array}$ & Total \\
\hline 2007 & 13 & 12 & 25 & 2 & 23 & 25 \\
\hline 2008 & 14 & 11 & 25 & 1 & 24 & 25 \\
\hline 2009 & 13 & 12 & 25 & 1 & 24 & 25 \\
\hline 2010 & 11 & 14 & 25 & 1 & 24 & 25 \\
\hline 2011 & 11 & 14 & 25 & 0 & 25 & 25 \\
\hline 2012 & 6 & 19 & 25 & 0 & 25 & 25 \\
\hline
\end{tabular}

Companies more than 500 million paid up capital expected Failure Company's decrease from 2007 to 2012 according to Z-Score Model and Abbas \& Rasheed Model show same result but more companies are non-failure.

In this study we uses two Models the Altman's and the model of the Abbas for investigating the status of financial measurement of the non-financial companies listed on the Karachi Stock Exchange. The non-financial is the largest slice listed in the KSE-100. The original model of the Altman was used in this study to analyze the significant difference between Z-Score and the Abbas model. Cut off points of the Abbas model and the Z-Score to rank the companies as financially distressed and non distressed were in line with the Altman and Courtis respectively. The result of the study showed that the application of these tools is significantly successful for judging the financial health of the non-financial companies listed at Karachi Stocks Exchange (KSE-100) and it may be used for the future research as a reliable and powerful tool.

After the development of the Altman's multivariate model, a number of researches and the studies are conducted by using the Z-Score Altman's model. Throughout the world, this model is constantly analyzed and applied by researchers. So, only these studies are conducted using the Z-Score model of Altman and Abbas model to test the reliability of the model practically. These models provide reliable or healthy results for determine the financial health of the company.

\section{Discussion \& Conclusion}

All fifty companies of non-financial sector are discussed in that results and the study of the research guide us that the Altman Z-Score and Abbas model both are significantly difference between expected financially failed and non failed companies in 2007, 2009, and 2010. But in 2008, 2011 and 2012 that are not significant. There exists significant positive correlation between the Altman's Z-Score and current Abbas model in 2007 to 2012. This positive correlation also supports the purpose of the study and adds the credibility to the analysis. 


\section{Mll Macrothink}

International Journal of Accounting and Financial Reporting

ISSN 2162-3082

2015, Vol. 5, No. 2

Findings suggest that using Abbas model and Z- Score is good predictor of assessing the financial health of the companies of non-financial listed at Karachi stock exchange in Pakistani context. This study provides an evidence for the acceptably of these models as a reliable tool.

The results also explored that there are expected financially failure companies in non-financial sector listed at Karachi Stock Exchange. Models results show decrease in expected failure companies from earlier period to ending time. Reasons behind that slump of developing economies and electricity down fall in earlier period of research sample (like 2007 to 2010).In practice the bankruptcies start in the companies where managers do not care about importance of internal control system and necessity of the data analysis. It is obvious that directors and managers in each company must have particular understanding about profitability, solvency, capital structure, cash flows and other financial indicators. Many bankrupt companies face problems in attaining financing in capital markets; but, it is the internal lack of managerial expertise in collecting and analyzing the necessary data that prevents company from bankruptcy.

Finally, the managers of bankrupt companies don't have a much experience or a accurate knowledge for the running of their firms. Even as the company's age and management experience increases, knowledge and vision remain critical deficiencies that con-tribute to failure. Every firm must find their own methods for doing their business stability and continuity and it might be constructed in manner that helps to identify the risk and to reduce or avoid the threat of bankruptcy. In finding the main cause of the company's bankruptcy it should not be amazing that this turns out to be the management inefficiency of the owners and the managers of the companies. Because of shortcoming in the financial knowledge and the managerial abilities the companies which are more likely to fail are the younger companies. In contrast, the firms which are older according to their life are more likely to fail due to the inability of settlement to environmental change. With the help of these conclusions we are in a position of getting new observation those are different causal mechanisms through which there are some firms which fail at early stage and there are some firms which fails at a later stage.

This study can be further expanded by the inclusion of other liquidity ratios. Another model of assessing financial health can also be used to test the reliability of the model. The Ohlson is another model for evaluating the financial health of the companies that could be used for the analysis. The research can also be expanded in other individual sector like textile, sugar, cement and telecommunication sector, which is the different slice of the listed companies of the Karachi Stock Exchange. Through this research we come to know that there is a need for the development of new models for assessing the financial health of the listed companies of Karachi Stock Exchange with the higher accuracy. The findings would provide help to corporate sector of Pakistan in timely monitoring and enhancing the financial position of the firms. By using that models findings, managers would be able to predict the early warning indicators and make corrective decisions. There are many other advantages that could come into motion. 


\section{Macrothink}

International Journal of Accounting and Financial Reporting

ISSN 2162-3082 2015, Vol. 5, No. 2

\section{Reference}

Abbas ,Q. \& Rashid,A. (2011). Modeling Bankruptcy Prediction for Non-Financial Firms: The Case of Pakistan.Munich Personal RePEc Archive, 28161:14

Agarwal,vineet, Tffler, and Richard J. (2007).Tweenty-five Years of the Z-score Model:Does It Really Have Predictive Ability? Accounting and Business Research 37(4):285-300.

Agarwal,V.and Taffler,R.J,(2008b), "Does Financial Distress Risk Drive the Momentum Anomaly”, Financial Management, Vol.37,No.3,p.461-484.

Altman, E. (1968). Financial ratios, discriminant analysis and the prediction of corporate bankruptcy. Journal of finance, 23(4), 589-609.

Altman, E., \& Saunders, A. (1997). Credit risk measurement: developments over the last 20 years. Journal of Banking \& Finance, 21(11), 1721-1742.

Altman, E.I., \& Edith Hotchkiss. (2006).Corporate financial distress and bankruptcy:Predict and avoid bankruptcy, analyze and invest in distressed debt.Hoboken,N.J.:Wiley.

Altman, E. I., Brenner, M. (1981). Information effects and stock market response to signs of firm deterioration The Journal of Financeand Quantitative Analyze,16(1),35.

Altman, E., Eom,Y.,\& Kim, D. (1995). Failure prediction: evidence from Korea. Journal of International Financial Management\&Accounting,6(3),230-249.

Beaver,W.H.(1966).Financial ratios as predictors of failure.Journal of Accounting Research,4(Empirical Research in Accounting:Slected Studies 1966),pp.71-111.

Bemmann, M.(2005).Improving the comparability of insolvency predictions. Dresden Economics Discussion Paper Series, 17.

Campbell,J.Y.,Hilscher,j.,\&Szilagyi,J.(2008).In search distress risk. The Journal of Finance,63(6),2899-2939.

Chava,S.and Purnanandum,A(2009),"Is stock Risk Negatively Related to Stock Risk?”

Dakovic ,R.;Czada, Cl, berg, D.2010.Bankruptcy prediction in Norway a comparision study,

Applied Economics Letters 17(17):1739-1746.

Dichev, I. (1998). Is the risk of bankruptcy a systematic risk? The Journal of Finance, 53(3), 1131-1147.

Eisenbeis, R. (1977). Pitfalls in the application of discriminant analysis in business, finance, and economics. Journal of finance, 32(3), 875-900.

Etemadi, H., Anvary, R. A., \& Dehkordi, H. (2009). A genetic programming model for bankruptcy prediction: empirical evidence from Iran. Expert Systems with Applications, 36(2), 3199-3207.

Griffin,J and Lemmon,L.(2002),"Book -to- Market Equity,Distress Risk, and Stock Return" Journal of Finance, Vol.57,No.5,p.2317-2336.

Guscinskiene,J.;Ciburiene,J.2010.Labour Situation,Contemporary, Business Management
Market in Litthuania:Gender and Education 2010 8(1):271-284. 


\section{Macrothink}

International Journal of Accounting and Financial Reporting

ISSN 2162-3082

Holl,s.(2007), “The influence of the business cycle on bankruptcy probability”, International

Transaction in Operational Research, Vol.14,P.75-90.

Merton, R. (1974). On the pricing of corporate debt: the risk structure of interest rates. Journal of finance, 29(2), 449-470.

Ohlson, J. (1980). Financial ratios and the probabilistic prediction of bankruptcy. Journal of Accounting Research,18(1), 109-131.

Rugenyte,D.;Menciuniene,V.;Dagiliene,L.2010.Bankroto prognozavimo svarba ir metodai, Verslas:teorija ir praktika, Business:Theory and Practice, 11(2):143-150.

Schumway, T. (2001). Forecasting bankruptcy more accurately: a simple hazard model. Journal of Business, 74(1), 101-124.

Taffler, Richard J.1982.The Assessment of company solvency and performance using a statistical model. Accounting and Business Research 15(52):295-308. 